
\title{
SINGLE-PHASE GRID-CONNECTED INVERTERS FOR PHOTOVOLTAIC MODULES: A CRITICAL REVIEW
}

\author{
Niharika Jain ${ }^{1}$, Santosh Kumar ${ }^{2}$ \\ E-Mail Id: jainniharika.jain@gmail.com ${ }^{1}$, santosh_en@ rediffmail.com ${ }^{2}$ \\ Department of Electrical \& Electronics Engineering, Millennium Institute of Technology \& Science, Bhopal \\ (Madhya Pradesh), India
}

\begin{abstract}
This review focuses on inverter technologies for connecting photovoltaic (PV) modules to a single-phase grid. The inverters are categorized into four classifications: 1) the number of power processing stages in cascade; 2) the type of power decoupling between the PV module(s) and the single-phase grid; 3) whether they utilizes a transformer (either line or high frequency) or not; and 4) the type of grid-connected power stage. Various inverter topologies are presented, compared, and evaluated against demands, lifetime, component ratings, and cost. Finally, some of the topologies are pointed out as the best candidates for either single PV module or multiple PV module applications.
\end{abstract}

Keywords: - AC module, photovoltaic (PV) power systems, single-phase grid-connected inverters.

\section{INTRODUCTION}

Photovoltaic (PV) power supplied to the utility grid is gaining more and more visibility, while the world's power demand is increasing [1]. Not many PV systems have so far been placed into the grid due to the relatively high cost, compared with more traditional energy sources such as oil, gas, coal, nuclear, hydro, and wind. Solid-state inverters have been shown to be the enabling technology for putting PV systems into the grid.

The price of the PV modules were in the past the major contribution to the cost of the systems. A down ward tendency is now seen in the price for the PV modules due to a massive increase in the production capacity of PV modules. The cost of the grid-connected inverter is, therefore, becoming more visible in the total system price. A cost reduction per inverter watt is, therefore, important to make PV-generated power more attractive [4]. Focus has, therefore, been placed on new, cheap, and innovative inverter solutions, which has resulted in a high diversity within the inverters, and new system configurations.

This paper starts with an examination of the demands for the inverters, set up by utility grid companies, the PV modules, and the operators. This is followed by a historical review to see how these demands were achieved in the past, how they are reached today, and perhaps how they will be realized in the future. Next follows an overview of some existing power inverter topologies for interfacing PV modules to the grid. The approaches are further discussed and evaluated in order to recognize the most suitable topologies for future PV inverters, and finally, a conclusion is given.

\section{SPECIFICATIONS, DEMANDS, AND STANDARDS}

Inverter interfacing PV module(s) with the grid involves two major tasks. One is to ensure that the PV module(s) is operated at the maximum power point (MPP). The other is to inject a sinusoidal current into the grid. These tasks are further reviewed in this section.

\subsection{Demands Defined by the Grid}

Since the inverter is connected to the grid, the standards given by the utility companies must be obeyed. In particular, the future international standard (still a Committee Draft for Vote CDV) IEC61727 [3] and the present standards EN61000-3-2 [4], IEEE1547 [5]. These standards deal with issues like power quality, detection of islanding operation, grounding, etc. The present EN standard is easier to cope with, regarding current harmonics, than the corresponding IEEE and IEC standards. This is also reflected in the chosen inverter topologies, which have changed from large thyristor-equipped grid-connected inverters to smaller insulated-gate-bipolar-transistor (IGBT)/MOSFET-equipped ones. The inverters must also be able to detect an islanding situation, and take appropriate measures in order to protect persons and equipment [7]. Islanding is the continued operation of the inverter when the grid has been removed on purpose, by accident, or by damage. In other words, the grid has been removed from the inverter, which then only supplies local loads. The available detection schemes are normally divided into two groups: active and passive. The passive methods do not have any influence on the power quality, since they just monitor grid parameters. The active schemes introduce a disturbance into the grid and monitor the effect. This may affect the power quality, and problems with multiple inverters in parallel with the grid are also known to exist [7], [8]. 


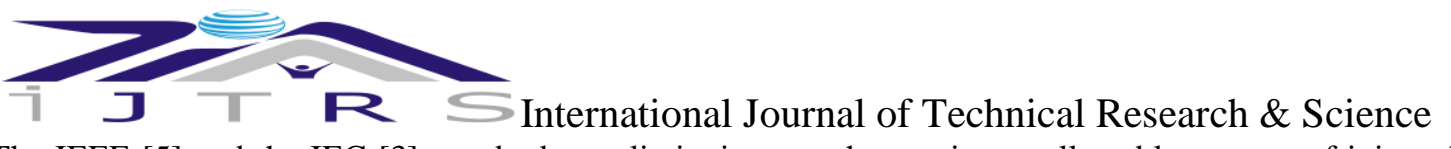

The IEEE [5] and the IEC [3] standards put limitations on the maximum allowable amount of injected dc current into the grid. The purpose of limiting the injection is to avoid saturation of the distribution transformers [7]. However, the limits are rather small $(0.5 \%$ and $1.0 \%$ of rated output current), and such small values can be difficult to measure precisely with the exciting circuits inside the inverters.

This can be mitigated with improved measuring circuits or by including a line-frequency transformer between the inverter and the grid. Some inverters use a transformer embedded in a high-frequency dc-dc converter for galvanic isolation between the PV modules and the grid. This does not, however, solve the problem with dc injection, but makes the grounding of the PV modules easier. The NEC 690 standard [6] demands that the PV modules shall be system grounded and monitored for ground faults, when the maximum output voltage of the PV modules reaches a certain level, e.g., $50 \mathrm{~V}$ [6], [7], [26]. System ground involves the negative (positive) terminal of the PV array(s) being connected to ground. This can be troublesome for many high-power transformer less systems, since a singlephase inverter with neutral-to-line grid connection already is system grounded on the grid side. Other Electricity Boards only demand equipment ground of the PV modules in the case of absent galvanic isolation [7], [9]. Equipment ground is the case when frames and other metallic parts are connected to ground.

Assuming that both the grid voltage and grid current only contain the fundamental component and that they are in phase, the instantaneous power injected into the grid becomes equal to

$$
P_{\text {grid }}=2 \cdot P_{\text {grid }} \sin ^{2}\left(\omega_{\text {grid }} t\right)
$$

Where $\mathrm{P}_{\text {grid }}$ the average is injected power, $\omega_{\text {grid }}$ is the angular frequency, and $\mathrm{t}$ is time.

\subsection{Demands Defined by the Photovoltaic Module(s)}

A model of a PV cell is shown in Fig. 2.1(a), and its electrical characteristic is illustrated in Fig. 2.1(b). The most common PV technologies nowadays are the monocrystalline and the multi crystalline-silicon modules, which are based on traditional, and expensive, microelectronic manufacturing processes [1]. The MPP voltage range for these PV modules is normally defined in the range from 23 to $38 \mathrm{~V}$ at a power generation of approximate $160 \mathrm{~W}$, and their open-circuit voltage is below $45 \mathrm{~V}$. However, new technologies like thin-layer silicon, amorphous-silicon, and photo Electro Chemical (PEC) are in development [1], [10].These types of PV modules can be made arbitrarily large by an inexpensive "roll-on-roll-off" process.

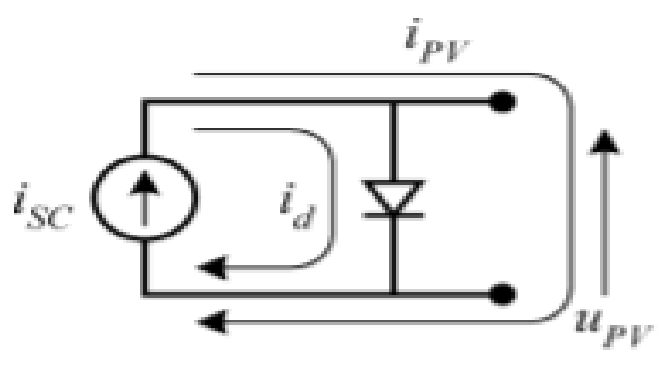

(a)

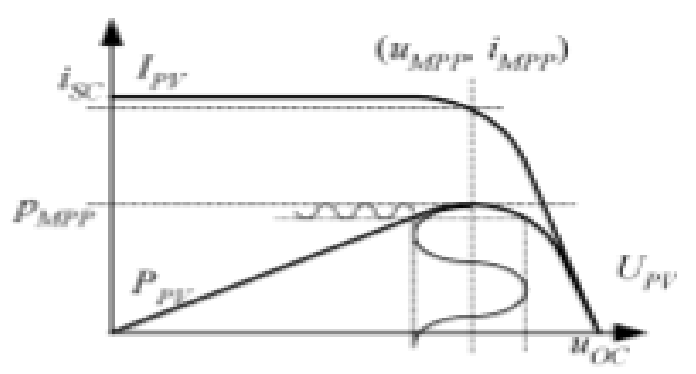

(b)

Fig. 2.1 Model and Characteristics of a PV Cell

(a) Electrical model with current and voltages defined. (b) Electrical characteristic of the PV cell, exposed to a given amount of (sun) light at a given temperature. As indicated, ripple at the PV module's terminals results in a somewhat lower power generation, compared with the case where no ripple is present at the terminals.

This means that new modules with only one cell may see the light in the future. The voltage range for these cells/modules is located around 0.5 to $1.0 \mathrm{~V}$ at several hundred amperes per square meter cell [11] - [13].

The inverters must guarantee that the PV module(s) is operated at the MPP, which is the operating condition where the most energy is captured. This is accomplished with an MPP tracker (MPPT). It also involves the ripple at the terminals of the PV module(s) being sufficiently small, in order to operate around the MPP without too much fluctuation. Analyses of the circuit in Fig. 1(a) show that there is a relationship between the amplitude of the voltage ripple and the utilization ratio.

\subsection{Demands Defined by the Operator}

The operator (the owner) also has a few words to say. First of all, the inverter must be cost effective, which is easily achieved with similar circuits as these used in today's single-phase power-factor-correction (PFC) circuits and variable-speed drives (VSDs). However, the user also demands a high efficiency over a wide range of input voltage 


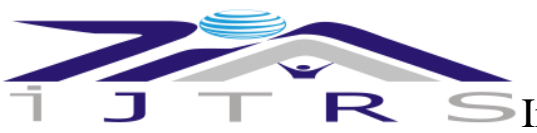

International Journal of Technical Research \& Science

and input power since these variables are defined in very wide ranges as functions of solar irradiation and ambient temperature. Fig. 2.2 shows the average irradiation during a normal year. The figure shows that most of the potential energy is available in the range from 50 to $1000 \mathrm{~W} / \mathrm{m}$ of irradiation. Further, the inverter must be highly reliable (long operational lifetime) since most PV module manufacturer offer a warranty of 25 years on $80 \%$ of initial efficiency, and a materials and workmanship warranty of five years [27]. The main limiting components inside the inverters are the electrolytic capacitors used for power decoupling between the PV module and the single-phase grid [16]-[19]. The operational lifetime for electrolytic capacitors is given by

$$
\mathrm{L}_{\mathrm{op}}=\mathrm{L}_{\mathrm{op}, \mathrm{o}} 2^{\left(\frac{\mathrm{T}_{0}-\mathrm{T}_{\mathrm{b}}}{\nabla \mathrm{T}}\right)}
$$

where $\mathrm{L}_{\mathrm{op}}$ is the operational lifetime, $\mathrm{L}_{\mathrm{op}, \mathrm{o}}$ is the lifetime at a hotspot temperature of $\mathrm{T}_{0}$, $\mathrm{T}_{\mathrm{b}}$ is the hotspot temperature, and $\nabla \mathrm{T}$ is the temperature increase which reduces the lifetime by a factor of two. However, the equation assumes a constant temperature, which can be approximated when the inverter is placed indoors and neglecting the power loss inside the capacitor, but certainly not when the inverter is integrated with the PV module, as for the ac module. In the case of a varying temperature a mean value of equation $\mathrm{L}_{\mathrm{op}}$ must be applied to determine the lifetime.

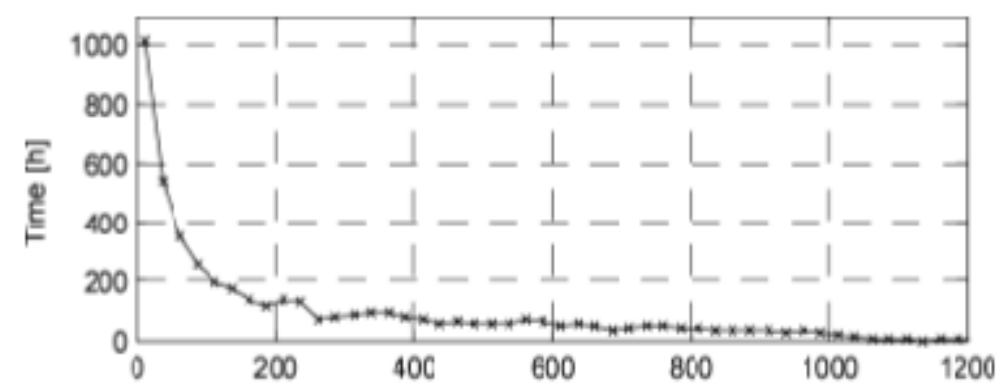

a)

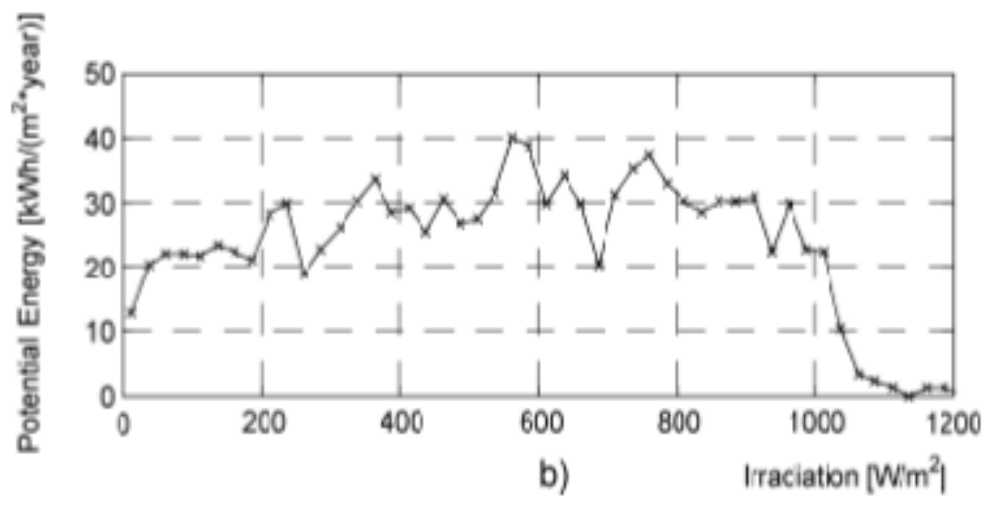

Fig. 2.2 Meteorological Data

(a) Irradiation distribution (b) Solar energy distribution. Total time of irradiation equals $4686 \mathrm{~h}$ per year. Total potential energy is equal to $1150 \mathrm{kWh}$ per $\left(\mathrm{m}^{2} \mathrm{y}\right)$.

\section{EVOLUTION OF PV INVERTERS}

The past technology, illustrated in Fig. 3.1, was based on centralized inverters that interfaced a large number of PV modules to the grid. The PV modules were divided into series connections (called a string), each generating a sufficiently high voltage to avoid further amplification. These series connections were then connected in parallel, through string diodes, in order to reach high power levels. This centralized inverter includes some severe limitations, such as high-voltage dc cables between the PV modules and the inverter, power losses due to a centralized MPPT, mismatch losses between the PV modules, losses in the string diodes, and a nonflexible design where the benefits of mass production could not be reached. The grid-connected stage was usually line commutated by means of thyristor, involving many current harmonics and poor power quality. The large amount of harmonics was the occasion of new inverter topologies and system layouts, in order to cope with the emerging standards which also covered power quality. 


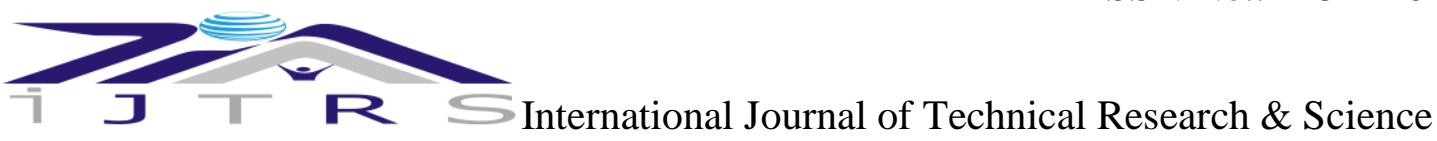

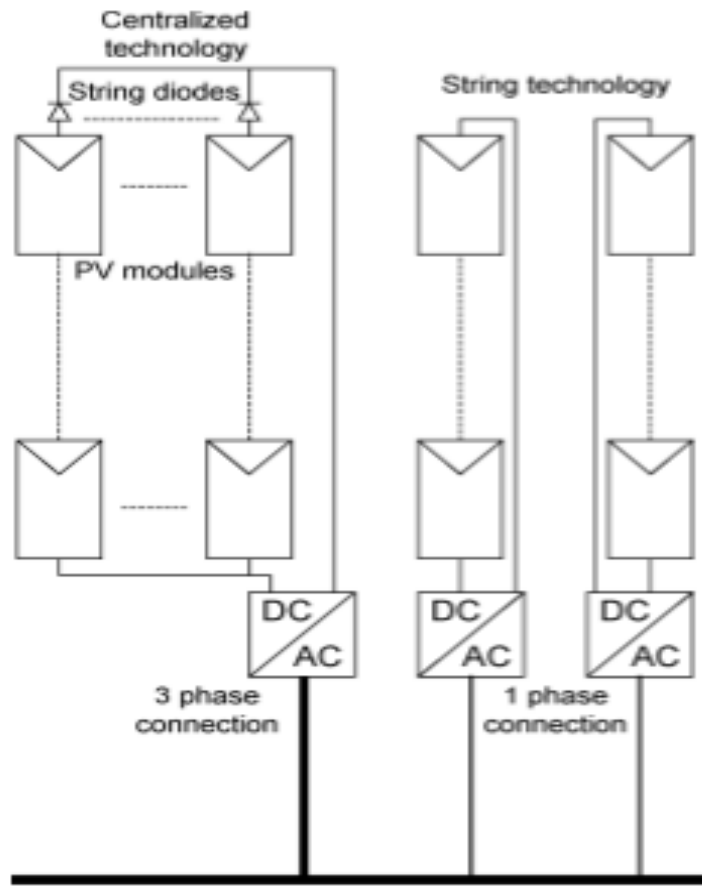

a) b)

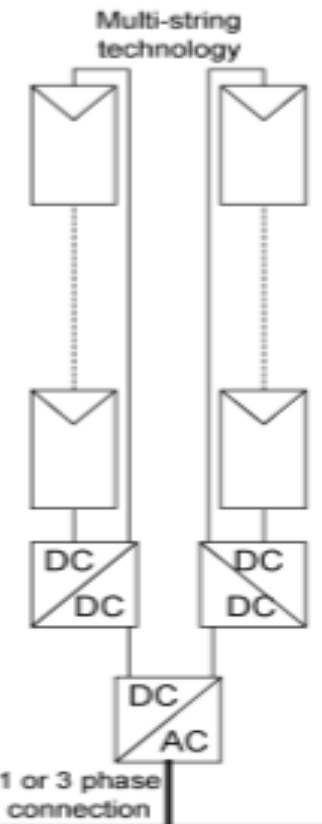

c)

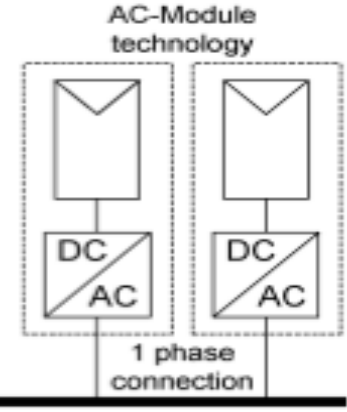

d)

Fig. 3.1 Historical overview of PV Inverters

(a) Past centralized technology. (b) Present string technology. (c) Present and future multi-string technology. (d) Present and future ac-module and ac cell technologies.

\section{CLASSIFICATIONS OF INVERTER TOPOLOGIES}

The topologies are categorized on the basis of number of power processing stages, location of power decoupling capacitors, if they employ transformers or not, and types of grid interface.

$>$ Number of Power Processing Stages

$>$ Power Decoupling

$>$ Transformers and Types of Interconnections

$>$ Types of Grid Interfaces

The number of power processing stages, in cascade, is the first grouping here. Fig. 4.1 shows three cases of singleand multiple stage inverters. Power decoupling is normally achieved by means of an electrolytic capacitor. As earlier, some inverters use a transformer embedded in a high-frequency dc-dc converter or dc-ac inverter, others use a line-frequency transformer toward the grid and, some inverters do not include a transformer at all. The linefrequency transformer is regarded as a poor component due to increased size, weight, and price. The grid-connected inverters topologies are line-frequency-commutated current-source inverters (CSIs). The current into the stage is already modulated/controlled to follow a rectified sinusoidal waveform and the task for the circuit is simply to recreate the sine wave and inject it into the grid. The circuits apply zero-voltage switching (ZVS) and zero-current switching (ZCS), thus, only conduction losses of the semiconductors remain.

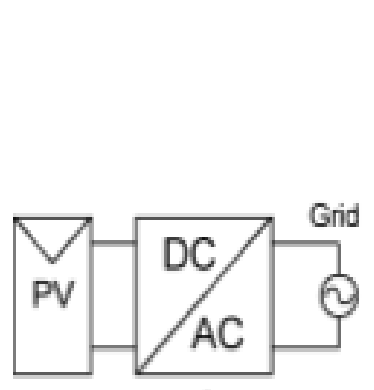

a)

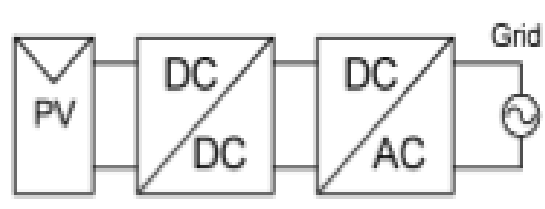

b)

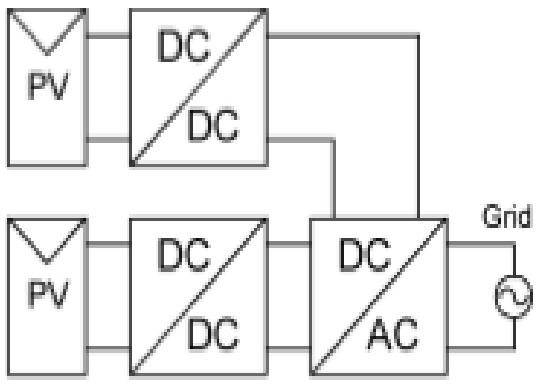

c)

Fig. 4.1 Three types of PV Inverters 


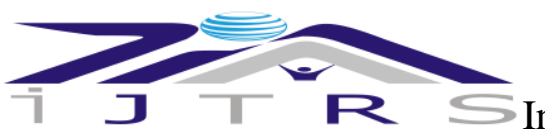

\section{International Journal of Technical Research \& Science}

Please note that the sign for the PV module shall be interpreted as either a single PV module, or as multiple PV modules in series/parallel connections. (a) A single power processing stage that handles the MPPT, voltage amplification, and grid current control. (b) Dual power processing inverter where the dc-dc converter is responsible for the MPPT and the dc-ac inverter control the grid current. Voltage amplification can be included in both stages. (c) Dual-stage inverter, where each PV module or string is connected to a dedicated dc-dc converter that is connected to a common dc-ac inverter.

\section{AC MODULES}

The ac Module is the combination of one PV module with a grid-connected inverter. The inverters should be of the dual-stage type with an embedded HF transformer. The presented ac module inverters have all been evaluated in [14] for component ratings, relative cost, lifetime, and efficiency. The ratings of the semiconductors are based on the average or rms currents and the peak voltages they have to withstand, together with a de-rating factor e.g., the PV side transistors in the inverter of Fig. 5.1 must withstand $90 \mathrm{~V}$ peak and 7.6-A rms, thus, their VA ratings are computed as $3.0 \mathrm{Kv}$ a each.

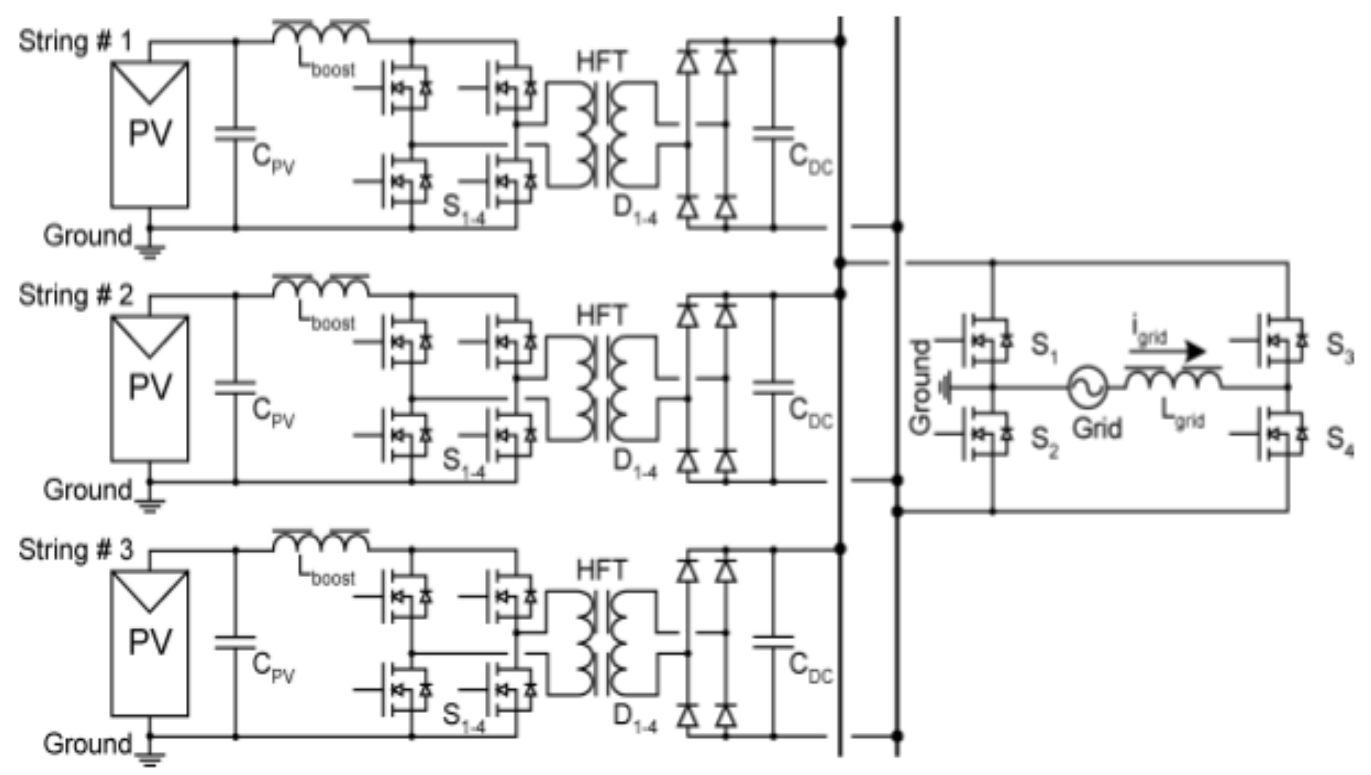

Fig. 5.1 Topology of the Power Electronics of the Three-String Inverter

\section{CONCLUSION}

This review has covered some of the standards that inverters for PV and grid applications must fulfill, which focus on power quality, injection of dc currents into the grid, detection of islanding operation, and system grounding. The demands stated by the PV modules have also been reviewed; in particular, the role of power decoupling between the modules and the grid has been investigated. Finally, the basic demands defined by the operator have also been addressed, such as low cost, high efficiency, and long lifetime. The next part of the review was a historical summary of the solutions used in the past, where large areas of PV modules were connected to the grid by means of centralized inverters. This included many shortcomings for which reason the string inverters emerged. A natural development was to add more strings, each with an individual dc-dc converter and MPPT, to the common dc-ac inverter, thus, the multi-string inverters were brought to light. This is believed to be one of the solutions for the future. Another trend seen in this field is the development of the ac module, where each PV module is interfaced to the grid with its own dc-ac inverter.

\section{REFERENCES}

[1] J.P.BennerandL.Kazmerski,"Photovoltaicsgaininggreatervisibility,” IEEE Spectr., vol. 29, no. 9, pp. 34-42, Sep. 1999.

[2] Trends in Photovoltaic Applications. Survey Report of Selected IEA Countries between 1992 and 2002. International Energy Agency Photovoltaic Power Systems, IEA PVPS T1-12:2003. [Online]. Available: www.iea-pvps.org

[3] Characteristics of the Utility Interface for Photovoltaic (PV) Systems, IEC 61727 CDV (Committee Draft for Vote), 2002.

DOI Number: https://doi.org/10.30780/IJTRS.V05.I05.001

pg. 5

WWw.ijtrs.com

WwW.ijtrs.org 


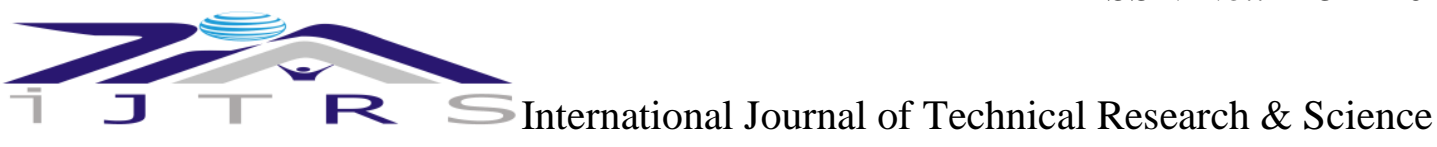

[4] Limits for Harmonic Current Emission (Equipment Input Current <16 A per Phase), EN 61000-3-2, 1995.

[5] IEEE Standard for Interconnecting Distributed Resources with Electric Power Systems, IEEE Std. 1547, 2003.

[6] National Electrical Code, National Fire Protection Association, Inc., Quincy, MA, 2002.

[7] B. Verhoeven et al. (1998) Utility Aspects of Grid Connected Photovoltaic Power Systems. International Energy Agency Photovoltaic Power Systems, IEA PVPS T5-01: 1998. [Online]. Available: www.iea-pvps.org

[8] J. H. R. Enslin and P. J. M. Heskes, "Harmonic interaction between a large number of distributed power inverters and the distribution network," in Proc. IEEE PESC'03, vol. 4, 2003, pp. 1742-1747.

[9] O. Willumsen, "Connection of solar systems," Danish Electricity Supply-Research and Development (DEFU), Copenhagen, Denmark, Tech. Rep. 501, 2003.

[10] E. Bezzel, H. Lauritzen, and S. Wedel. (2004) the photo electro chemical solar cell. PEC Solar Cell Project, Danish Technological Institute. [Online]. Available: www.solarcell.dk

[11] H. Wilk, D. Ruoss, and P. Toggweiler. (2002) Innovative electrical concepts. International Energy Agency Photovoltaic Power Systems, IEA PVPS 7-07:2002. [Online]. Available: www.iea-pvps.org

[12] M. Wuest, P. Toggweiler, and J. Riatsch, "Single cell converter system (SCCS)," in Proc. 1st IEEE WCPEC, vol. 1, 1994, pp. 813-815.

[13] J. Riatsch, H. Stemmler, and R. Schmidt, "Single cell module integrated converter system for photovoltaic energy generation," in Proc. EPE'97, vol. 1, Trondheim, Norway, 1997, pp. 71-77.

[14] S. B. Kjaer, "Design and control of an inverter for photovoltaic applications," Ph.D. dissertation, Inst. Energy Technol., Aalborg University, Aalborg East, Denmark, 2004/2005.

[15] S.Poulsen, “GlobalandDanishreferenceyearirradiation,”DanishTechnological Inst., Taastrup, Denmark, 2002.

[16] H. Oldenkamp, I. J. de Jong, C. W. A. Baltus, S. A. M. Verhoeven, and S. Elstgeest, "Reliability and accelerated life tests of the AC module mountedOKE4inverter,"in|Proc.IEEE Photovoltaic Specialists Conf., 1996, pp. 1339-1342.

[17] P. Rooij, M. Real, U. Moschella, T. Sample, and M. Kardolus. (2001) Advanced Reliability Improvements of AC-Modules (ARIA), ECN-C-01-093. Netherlands Energy Research Foundations (ECN). [Online]. Available: www.ecn.nl

[18] M. Calais, J. Myrzik, T. Spooner, and V. G. Agelidis, "Inverters for single-phase grid connected photovoltaic systems-An overview," in Proc. IEEE PESC'02, vol. 2, 2002, pp. 1995-2000.

[19] Y. Xue, L. Chang, S. B. Kjaer, J. Bordonau, and T. Shimizu, "Topologies of single-phase inverters for small distributed power generators: an overview," IEEE Trans. Power Electron., vol. 19, no. 5, pp. 1305-1314, Sep. 2004.

[20] F. Blaabjerg, Z. Chen, and S. B. Kjaer, "Power electronics as efficient interface in dispersed power generation systems," IEEE Trans. Power Electron., vol. 19, no. 5, pp. 1184-1194, Sep. 2004.

[21] M. Meinhardtand G. Cramer," Past, present and future of grid connected photovoltaic- and hybrid-powersystems," in Proc. IEEE-PES Summer Meeting, vol. 2, 2000, pp. 1283-1288.

[22] M. Calais and V. G. Agelidis, "Multilevel converters for single-phase grid connected photovoltaic systems - an overview," in Proc. IEEE ISIE'98, vol. 1, 1998, pp. 224-229.

[23] J. M. A. Myrzik and M. Calais, "String and module integrated inverters for single-phase grid connected photovoltaic systems-A review," in Proc. IEEE Bologna PowerTech Conf., vol. 2, 2003, pp. 430-437.

[24] S.B.Kjaer, J.K.Pedersen, andF.Blaabjerg,"Power inverter topologies for photovoltaic modules-A review," in Conf. Rec. IEEE-IAS Annu. Meeting, vol. 2, 2002, pp. 782-788.

[25] H. Haeberlin, "Evolution of inverters for grid connected PV-systems from 1989 to 2000,"in Proc. $17^{\text {th }}$ Eur. Photovoltaic Solar Energy Conf., Munich, Germany, Oct. 22-26, 2001, pp. 426-430.

[26] M. Meinhardt, T. O'Donnell, H. Schneider, J. Flannery, C. O. Mathuna, P. Zacharias, and T. Krieger, "Miniaturised 'low profile' module integrated converter for photovoltaic applications with integrated magnetic components," in Proc. IEEE APEC'99, vol. 1, 1999, pp. 305-311.

[27] N. P. Papanikolaou, E. C. Tatakis, A. Critsis and D. Klimis, "Simplified high frequency converter in decentralized grid-connected PV systems: a novel low-cost solution,” in Proc. EPE’03, 2003, CD-ROM.

[28] T. Shimizu, K. Wada, and N. Nakamura, "A flyback-type single phase utility interactive inverter with lowfrequency ripple current reduction on the DC input for an AC photovoltaic module system," in Proc. IEEE PESC'02, vol. 3, 2002, pp. 1483-1488.

[29] S. B. Kjaer and F. Blaabjerg, "Design optimization of a single phase inverter for photovoltaic applications," in Proc. IEEE PESC'03, vol. 3, 2003, pp. 1183-1190.

[30] M. Nagao and K. Harada, "Power flow of photovoltaic system using buck-boost PWM power inverter," in Proc. PEDS'97, vol. 1, 1997, pp. 144-149.

[31] M. Meinhardt and P. Mutschler, "Inverters without transformer in grid connectedphotovoltaicapplications,"inProc.EPE’95, vol.3, 1995, pp. 86-91. 
ᄀ 7 R $S$ International Journal of Technical Research \& Science

[32] T. Shimizu, M. Hirakata, T. Kamezawa, and H. Watanabe, "Generation control circuit for photovoltaic modules,” IEEE Trans. Power Electron., vol. 16, no. 3, pp. 293-300, May 2001.

[33] T. Shimizu, O. Hashimoto, and G. Kimura, "A novel high-performance utility-interactive photovoltaic inverter system," IEEE Trans. Power Electron., vol. 18, no. 2, pp. 704-711, Mar. 2003.

[34] (2005, Jan.) Sunny Boy 5000TL Multi-String-Operating Instructions, SMA. [Online]. Available: www.sma.de

[35] C. Dorofte, "Comparative analysis of four $\mathrm{dc} / \mathrm{dc}$ converters for photovoltaic grid interconnection," Aalborg Univ./Powerlynx A/S, Aalborg East, Denmark, Tech. Rep., 2001.

[36] "Design of a de/dc converter for photovoltaic grid interconnection," Aalborg Univ./Powerlynx A/S, Aalborg East, Denmark, Tech. Rep., 2001. 